\title{
Urinary iodine and serum 25-hydroxyvitamin D are associated with depression in adolescents
}

\author{
Wei Huang, Dehong Gong*, Yongbo Bao \\ Department of Pediatric Care, Zaozhuang City Hospital, Zaozhuang 277100, China \\ *For correspondence: Email: Gongdehongllk@163.com
}

Sent for review: 23 July 2018

Revised accepted: 19 November 2018

\begin{abstract}
Purpose: To determine whether depressive disorder (DD) in adolescents is associated with the levels of serum 25-hydroxyvitamin $D\{25(\mathrm{OH}) \mathrm{D}\}$ and urinary iodine.

Methods: A total of 270 adolescent participants from 8 to 16 years old were enrolled in this study (male, $n=125$; female, $n=145$ ). Of these, 160 paticipants (male, $n=75$; female, $n=85$ ) were diagnosed with $D D$ and 110 paticipants (male, $n=50$; female, $n=60$ ) were non-DD. Urinary iodine level, serum 25(OH)D level, and thyroid function were measured and adjusted for sex, age, body mass index, and disease progression. Vitamin $D(25(\mathrm{OH}) \mathrm{D})<15 \mathrm{ng} / \mathrm{mL}$ was considered as VD deficiency, and iodine $<100 \mu \mathrm{g} / \mathrm{L}$ was viewed as iodine deficiency. Mean VD and iodine levels were compared between DD and control groups.

Results: $D D$ patients had lower concentrations of $25(\mathrm{OH}) D_{3}(p<0.005)$ and urinary iodine $(p<0.05)$ than non-DD control, in both male and female cohorts. However, serum $25(\mathrm{OH}) \mathrm{D}_{2}$ concentration did not significantly correlate with depressive symptoms.

Conclusion: Adolescents with $D D$ have markedly lower serum 25(OH)D concentrations and urinary iodine levels than control patients. This relationship is positively associated with disease progression, suggesting possible nutritional intervention measures for neuroprotection.
\end{abstract}

Keywords: 25-Hydroxyvitamin D, lodine, Adolescence, Depression

\begin{abstract}
This is an Open Access article that uses a funding model which does not charge readers or their institutions for access and distributed under the terms of the Creative Commons Attribution License (http://creativecommons.org/licenses/by/4.0) and the Budapest Open Access Initiative (http://www.budapestopenaccessinitiative.org/read), which permit unrestricted use, distribution, and reproduction in any medium, provided the original work is properly credited.

Tropical Journal of Pharmaceutical Research is indexed by Science Citation Index (SciSearch), Scopus, International Pharmaceutical Abstract, Chemical Abstracts, Embase, Index Copernicus, EBSCO, African Index Medicus, JournalSeek, Journal Citation Reports/Science Edition, Directory of Open Access Journals (DOAJ), African Journal Online, Bioline International, Open-J-Gate and Pharmacy Abstracts
\end{abstract}

\section{INTRODUCTION}

Depressive disorder (DD) is common and affects $1-6 \%$ of adolescents worldwide [1]. The Global Burden of Disease report estimated that the social and economic loss due to DD is as substantial as the burden caused by cardiovascular and cancer diseases [2]. Recent studies have demonstrated that DD is associated with lower vitamin $D$ in adults, but this association has not yet been studied in adolescents [3].

It is well known that $25(\mathrm{OH}) \mathrm{D}$ primarily participates in calcium homeostasis[4]. In addition, many studies have demonstrated that $25(\mathrm{OH}) \mathrm{D}$ is associated with cancer, diabetes, cardiovascular disease, and obesity [5-8]. Thus, it has been hypothesized that $25(\mathrm{OH}) \mathrm{D}$ may participate in maintaining the function of cognition. It reported that high 25(OH)D 
concentrations may protect against depression in adults [9]. Interestingly, three randomized controlled trials reported that vitamin $D_{3}$ supplements improved depression symptoms in obese adults [10], however, further vitamin $D_{3}$ supplement trials had no significant effect on symptom improvement in elderly subjects [11].

lodine is essential for thyroid hormone synthesis [12]. However, there is currently no clear data regarding the effect of iodine levels in depressive disease [13]. In fact, in response to reserved radioactive iodine therapy, many patients displayed symptoms of hypothyroidism, including fatigue, sleep disturbance, and depression, likely due to iodine imbalance in the body [14].

In the current study, the relationships between serum 25(OH)D concentrations, iodine levels, and depressive symptoms in adolescents were explored. Additionally, the relationships among depression and many factors, such as sex, age, body mass index (BMI), and social status were also investigated to explore the effects of iodine intake and vitamin D levels on DD in the population.

\section{EXPERIMENTAL}

\section{Participants}

A total of 270 participants were enrolled (125 males and 145 females) from March 2016 to May 2018. All participants were $8-16$ years old and had a BMI ranging from the 5th to 95th percentiles. DD (75 males and 85 females) was diagnosed by local psychiatrists. Healthy control subjects (50 males and 60 females) were enlisted from outpatient pediatric health care centers affiliated with the Zaozhuang, City Hospital for Children. Adolescents who received medical treatments that could affect thyroid function in the preceding 2 months were excluded. Adolescents with suicidal ideation were also excluded. Informed consent was obtained from all participants. This study was approved by the Ethics Committee of Zaozhuang City Hospital.

\section{Psychological health assessment}

Under the supervision of professional investigators, mental health assessments were carried out by self-reported mental health questionnaire. Depressive symptoms included feeling despair and/or sad continuously for more than 2 weeks to a point that interferes with normal study and life. According to the questionnaire results, all participants were grouped into two groups: a "depression" group and a "non-depression" group. Depression was assessed as previously described $[15,16]$.

\section{Data collection}

Blood and urine samples were collected as a part of the clinical routine at admission. After consent was given and within an hour of collection, the samples were transferred at $4^{\circ} \mathrm{C}$ according to approved standard operation procedures to the clinical laboratory of the Zaozhuang City Hospital. The levels of thyroid-stimulating hormone FT4, serum $25(\mathrm{OH}) \mathrm{D}$ and urinary iodine were measured using ELISA Kits. Vitamin $D<15$ $\mathrm{ng} / \mathrm{mL}$ was defined as vitamin $D$ deficiency [17] and iodine $<100 \mu \mathrm{g} / \mathrm{L}$ was defined as iodine deficiency. The levels of vitamin $D$ and iodine were compared between control (non-DD) and DD groups.

\section{Statistical analysis}

Student's t-test, analysis of variance (ANOVA) and Pearson's Chi-squared test were performed using SPSS 25.0. $P<0.05$ was considered statistically significant.

\section{RESULTS}

\section{Clinical characteristics of the subjects}

The clinical characteristics of the control and DD subjects are generalized in Table 1. DD patients displayed no difference from healthy control subjects in height, weight, and age. However, females with DD had a higher BMI $(p=0.04)$. None of the males with DD was hypogonadal, and all females with DD had normal menses. There was also no difference observed in the thyroid hormone, FT4, level between the DD and control groups. Differences in smoking and drinking history between DD and control groups were analyzed. Tobacco use was more frequent in females with DD than control subjects $(p=$ 0.01 ). Additionally, there were more male $D D$ patients with smoking and drinking history than female DD patients. Fifty-eight males and 70 females were using selective serotonin reuptake inhibitors (SSRIs), and 24 males and 31 females were using atypical antipsychotics.

\section{Serum 25(OH)D and urinary iodine levels in DD and control groups}

The levels of serum $25(\mathrm{OH}) \mathrm{D}_{2}$, serum $25(\mathrm{OH}) \mathrm{D}_{3}$, and urinary iodine were evaluated in participants. Serum $25(\mathrm{OH}) \mathrm{D}_{2}$ concentrations were not closely related to depressive symptoms in adolescents (data not shown). 
Table 1: Clinical characteristics of males and females with DD and healthy control participants

\begin{tabular}{|c|c|c|c|c|c|c|}
\hline \multirow[b]{2}{*}{ Variable } & \multicolumn{2}{|c|}{ Male } & \multirow[t]{2}{*}{$P$-value } & \multicolumn{2}{|c|}{ Female } & \multirow[t]{2}{*}{$P$-value } \\
\hline & $\mathrm{DD}(\mathrm{n}=75)$ & $\begin{array}{l}\text { Ctrls } \\
(n=50)\end{array}$ & & $\mathrm{DD}(\mathrm{n}=85)$ & Ctrls $(n=60)$ & \\
\hline Age (years) & $12.1 \pm 2.6$ & $11.6 \pm 2.8$ & 0.28 & $12.0 \pm 2.7$ & $12.3 \pm 2.8$ & 0.62 \\
\hline Height (cm) & $149.4 \pm 18.0$ & $154.0 \pm 17.5$ & 0.11 & $129.7 \pm 16.3$ & $132.9 \pm 19.8$ & 0.28 \\
\hline Weight (kg) & $50.2 \pm 11.7$ & $52.2 \pm 12.0$ & 0.34 & $37.2 \pm 9.3$ & $38.1 \pm 10.8$ & 0.57 \\
\hline BMI $\left(\mathrm{kg} / \mathrm{m}^{2}\right)$ & $22.2 \pm 1.3$ & $21.6 \pm 2.0$ & 0.06 & $21.9 \pm 2.1$ & $21.2 \pm 1.5$ & $0.04^{*}$ \\
\hline $\begin{array}{l}\text { DD subjects with } \\
\text { history of SSRI use }\end{array}$ & $58.7 \%$ & & & $70.6 \%$ & & \\
\hline $\begin{array}{l}\text { DD subjects with } \\
\text { history of atypical } \\
\text { antipsychotic use }\end{array}$ & $24.0 \%$ & & & $31.8 \%$ & & \\
\hline History of smoking & $17.3 \%$ & $10 \%$ & & $5.8 \%$ & $0 \%$ & $0.01^{*}$ \\
\hline History of alcohol & $25.3 \%$ & $16.6 \%$ & & $0 \%$ & $0 \%$ & \\
\hline FT4 (pmol/L) & $22.0 \pm 4.5$ & $22.6 \pm 4.3$ & 0.08 & $22.4 \pm 3.0$ & $23.6 \pm 3.4$ & 0.38 \\
\hline
\end{tabular}

The mean concentrations of total serum $25(\mathrm{OH}) \mathrm{D}\left[25(\mathrm{OH}) \mathrm{D}_{2}+25(\mathrm{OH}) \mathrm{D}_{3}\right]$ in $\mathrm{DD}$ and control participants were $17.4 \pm 4.3$ and $22.9 \pm$ $5.0 \mathrm{ng} / \mathrm{mL}$, respectively. In addition, the mean concentrations of urinary iodine in DD and control participants were $175.7 \pm 66.5$ and 250.8 $\pm 88.6 \mathrm{ng} / \mathrm{mL}$, respectively. The results indicate that both serum $25(\mathrm{OH}) \mathrm{D}$ and urinary iodine levels were significantly lower in DD adolescents than in the control subjects, suggesting a close relationship between DD $25(\mathrm{OH}) \mathrm{D}$, and iodine levels in vivo.

\section{Age and sex index}

Serum 25(OH)D concentrations varied significantly with sex and age (Table 2). For children 8 to 12 years old, $3.2 \%$ had 25(OH)D levels $<12 \mathrm{ng} / \mathrm{mL}$, and $45.2 \%$ had $25(\mathrm{OH}) \mathrm{D}$ levels $<20 \mathrm{ng} / \mathrm{mL}$. In contrast, these levels were 10.4 and $54.9 \%$ for teenagers 8 - 16 years old, respectively. For children 8 to 11 years old, 2.4 $\%$ had iodine levels $<100 \mu \mathrm{g} / \mathrm{L}$, and $76.2 \%$ had iodine levels $<300 \mu \mathrm{g} / \mathrm{L}$. For teenagers 8 to 16 years old, $13.9 \%$ had iodine levels $<100 \mu \mathrm{g} / \mathrm{L}$, and $80.6 \%$ had iodine levels $<300 \mu \mathrm{g} / \mathrm{L}$. Regardless of gender, the mean levels of $25(\mathrm{OH}) \mathrm{D}$ and iodine were lower for teenagers than children (Figure 1A). Otherwise, > $19 \%$ of adolescents had urinary iodine levels $<300 \mu \mathrm{g} / \mathrm{L}$, and this value was lower in DD patients compared with normal control participants. The mean value of iodine among females 12 to 16 years old was $179.1 \mu \mathrm{g} / \mathrm{L}$, which was lower than that of males $(184.2 \mu \mathrm{g} / \mathrm{L})$ of the same age (Figure 1B).
A

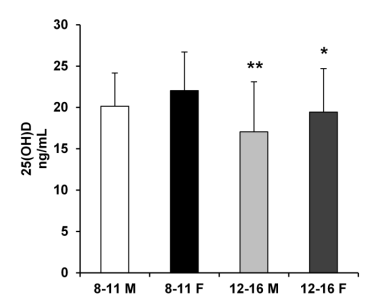

B

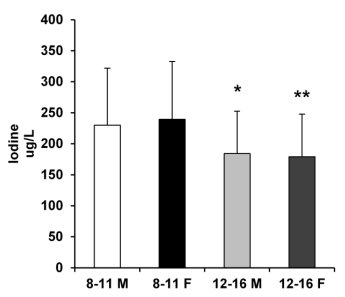

Figure 1: Serum $25(\mathrm{OH}) \mathrm{D}$ and urinary iodine values by age and sex. (A) The level of serum $25(\mathrm{OH}) \mathrm{D}$ was measured. (B) The level of urinary iodine was measured. $P$-values indicate significant differences between 8-11 years and 12-16 years of the same gender. t-test analysis was used for the comparison. ${ }^{*} p<0.05,{ }^{* *} p<0.01$. $\square$ : 8-11 year-old males; $\square: 8-$ 11 year-old females; $\square: 12-16$ year-old males; $\square: 12-$ 16 year-old females

Table 2: Serum $25(\mathrm{OH}) \mathrm{D}$ and urinary iodine values of males and females

\begin{tabular}{|c|c|c|c|c|c|c|c|c|c|c|c|}
\hline \multirow[b]{2}{*}{ Biomarker } & & \multicolumn{5}{|c|}{ Males } & \multicolumn{5}{|c|}{ Females } \\
\hline & & $8-11 y$ & & 12-16y & & $P$ & $8-11 y$ & & 12-16y & & $P$ \\
\hline $25(\mathrm{OH}) \mathrm{D}$ & $<12 n g / m L$ & $11.1 \pm 0.7$ & $3.2 \%$ & $10.5 \pm 1.1$ & $11.1 \%$ & $0.027^{\star}$ & $11.3 \pm 0.2$ & $3.1 \%$ & $10.5 \pm 1.3$ & $43.8 \%$ & $0.000^{\star}$ \\
\hline & $<20 \mathrm{ng} / \mathrm{mL}$ & $17.5 \pm 1.7$ & $\begin{array}{c}46.8 \\
\%\end{array}$ & $15.7 \pm 1.9$ & $65.1 \%$ & $0.000^{\star}$ & $17.1 \pm 2.3$ & $9.9 \%$ & $16.9 \pm 2.2$ & $46.9 \%$ & $0.000^{*}$ \\
\hline lodine & $\begin{array}{l}<100 \mu \mathrm{g} / \mathrm{L} \\
<300 \mu \mathrm{g} / \mathrm{L}\end{array}$ & $\begin{array}{c}99.1 \pm 0.5 \\
193.5 \pm 45 \\
8\end{array}$ & $\begin{array}{c}3.2 \% \\
74.2 \\
\%\end{array}$ & $\begin{array}{c}94.8 \pm 5.2 \\
180.5 \pm 3 \\
1.8\end{array}$ & $\begin{array}{l}14.0 \% \\
76.2 \%\end{array}$ & $\begin{array}{c}\mathbf{0 . 0 0 7 ^ { * }} \\
0.3\end{array}$ & $\begin{array}{c}97.5 \pm 1.0 \\
203.7 \pm 55 \\
4\end{array}$ & $\begin{array}{c}1.2 \% \\
78.1 \\
\%\end{array}$ & $\begin{array}{c}85.3 \pm 12.0 \\
189.7 \pm 57 \\
6\end{array}$ & $\begin{array}{l}13.6 \% \\
83.9 \%\end{array}$ & $\begin{array}{l}0.000^{*} \\
0.001^{*}\end{array}$ \\
\hline
\end{tabular}

Data are presented as mean \pm SD; $p$-values represent comparison between 8 - and $12-16$ year old cohort; ${ }^{*} \mathrm{t}-$ test and Pearson's chi-square were used to analyze differences between groups 
Association between serum 25(OH)D, urinary iodine, and depressive symptoms

The mean value of serum $25(\mathrm{OH}) \mathrm{D}$ in teenagers with DD was $15.8 \pm 3.7 \mathrm{ng} / \mathrm{mL}$, whereas that of teenagers without DD was $22.4 \pm 4.4 \mathrm{ng} / \mathrm{mL}$. The mean levels of serum $25(\mathrm{OH}) \mathrm{D}$ in children with DD was $19.4 \pm 4.2 \mathrm{ng} / \mathrm{mL}$, whereas that of the controls was $23.3 \pm 5.6 \mathrm{ng} / \mathrm{mL}$. Thus, serum $25(\mathrm{OH}) \mathrm{D}$ levels of both teenagers and children with DD were markedly lower than those of agematched control participants without DD. Moreover, serum 25(OH)D levels of teenagers were significantly lower than those of children (811-year-olds) with DD, but this difference was not observed among healthy controls (Table 3).

The mean serum 25(OH)D levels and urinary iodine levels of adolescents with DD were reduced when compared with the control participants in each social class. However, no statistically significant differences were found between social classes in DD or control subjects. High concentrations of urinary iodine were closely related to lower risk of depression at ages $12-16$ and at ages 8-11. Table 3 also shows that the urinary iodine concentration in teenagers with DD was $149.5 \pm 49.9 \mu \mathrm{g} / \mathrm{L}$ whereas that of teenagers without DD was $231.4 \pm 63.6 \mu \mathrm{g} / \mathrm{L}$. The mean urinary iodine level of children with DD was $207.7 \pm 70.5 \mu \mathrm{g} / \mathrm{L}$ whereas that of the control subjects was $270.6 \pm 105.9 \mu \mathrm{g} / \mathrm{L}$. There was a statistical association of iodine values with depressive symptoms in adolescents of every social class.

\section{Analysis of the correlation between urinary iodine and vitamin D in DD}

Next, the prevalence of depression according to serum 25(OH)D levels and urinary iodine concentrations was examined (Table 4). In the $25(\mathrm{OH}) \mathrm{D}$ deficient group, the prevalence of depression was higher in iodine deficiency (5.6 $\%)$ than with iodine adequacy $(0.6 \%)$. In both the $25(\mathrm{OH}) \mathrm{D}$ sufficient and insufficient groups, there was no significant association between the prevalence of depression and iodine deficiency. The same analysis was conducted in the control group. Among the control participants, there was also a significant association between $25(\mathrm{OH}) \mathrm{D}$ and iodine intake in the $25(\mathrm{OH}) \mathrm{D}$ deficient group.

\section{DISCUSSION}

Although the association between dietary patterns and depression risk has been proposed recently [18-20], only a few investigations have analyzed the association between micronutrient status and incidence of chronic diseases, such as DD.

Table 3: Relationships among age, social class, serum $25(\mathrm{OH}) \mathrm{D}$, and urinary iodine, and depressive symptoms

\begin{tabular}{|c|c|c|c|c|c|c|}
\hline \multirow[t]{2}{*}{ Variable } & DD & $\begin{array}{l}\text { Ctrlsnon- } \\
\text { DD }\end{array}$ & $P$-value & DD & Ctrlsnon-DD & $P$-value \\
\hline & \multicolumn{3}{|c|}{ Serum 25(OH)D levels } & \multicolumn{3}{|c|}{ Urinary iodine levels } \\
\hline \multicolumn{7}{|l|}{ Age group } \\
\hline $8-11$ years & $19.4 \pm 4.2$ & $23.3 \pm 5.6$ & $0.000^{\circ}$ & $207.7 \pm 70.5$ & $270.6 \pm 105.9$ & 0.000 \\
\hline $12-16$ years & $15.8 \pm 3.7$ & $22.4 \pm 4.4$ & $0.000^{\circ}$ & $149.5 \pm 49.9$ & $231.4 \pm 63.6$ & $0.000^{\prime}$ \\
\hline$P$-value & $0.000^{\star}$ & 0.34 & & 0.000 & 0.02 & \\
\hline \multicolumn{7}{|l|}{ Social class } \\
\hline Upper social class & $17.8 \pm 2.5$ & $21.5 \pm 3.3$ & $0.000^{*}$ & $187.5 \pm 76.4$ & $258.5 \pm 99.4$ & $0.000^{\pi}$ \\
\hline Middle social class & $16.9 \pm 3.2$ & $21.7 \pm 4.2$ & $0.000^{\circ}$ & $176.5 \pm 84.7$ & $248.9 \pm 101.3$ & $0.000^{\prime}$ \\
\hline Lower social class & $16.3 \pm 4.1$ & $22.5 \pm 5.2$ & $0.000^{\circ}$ & $174.3 \pm 88.4$ & $244.6 \pm 78.4$ & 0.000 \\
\hline$P$-value & 0.56 & 0.73 & & 0.94 & 0.84 & \\
\hline
\end{tabular}

Table 4: Prevalence of DD stratified by serum 25(OH)D and urinary iodine levels

\begin{tabular}{|c|c|c|c|c|}
\hline \multirow[b]{2}{*}{ 25(OH)D group } & \multirow[b]{2}{*}{ Deficiency } & \multicolumn{2}{|c|}{ Urinary iodine group } & \multirow[b]{2}{*}{$P$-value } \\
\hline & & Adequate & Excessive & \\
\hline \multicolumn{5}{|l|}{$\mathrm{DD}$} \\
\hline Deficiency & $9(5.6 \%)$ & 7 (4.4\%) & $1(0.6 \%)$ & 0.000 \\
\hline Insufficiency & $11(6.9 \%)$ & $87(54.4 \%)$ & $5(3.1 \%)$ & \\
\hline Sufficiency & $4(2.5 \%)$ & $34(21.3 \%)$ & $2(1.3 \%)$ & \\
\hline \multicolumn{5}{|l|}{ Ctrls } \\
\hline Deficiency & $1(0.9 \%)$ & $1(0.9 \%)$ & $1(0.9 \%)$ & 0.017 \\
\hline Insufficiency & 0 & $23(20.9 \%)$ & $9(8.2 \%)$ & \\
\hline Sufficiency & $2(1.8 \%)$ & $55(50.0 \%)$ & $18(16.4 \%)$ & \\
\hline
\end{tabular}

Data are presented as mean \pm SD; $p$-values are based on comparison between DD cohort and non-DD cohort; * T-test and Pearson's Chi-square were used to analyze differences between groups 
For example, low serum levels of folate, $25(\mathrm{OH}) \mathrm{D}$, or zinc have been reported to be related to depressive symptoms in clinical studies [21-23]. These findings suggest that micronutrient deficiencies are directly associated with increased risk of developing DD. In the present study, the possible association between the levels of serum $25(\mathrm{OH}) \mathrm{D}$ or urinary iodine and depression was explored in Chinese adolescents. A previous finding showed that adolescents with psychotic manifestations had lower serum 25(OH)D levels [24]. Another clinical study also found that participants with major depression or schizophrenia had lower $25(\mathrm{OH}) \mathrm{D}_{3}$ levels [25]. Moreover, a study in patients with mild Alzheimer's disease demonstrated that subjects with lower 25(OH)D levels $(<20.0$ $\mathrm{ng} / \mathrm{mL}$ ) were more susceptible to mood disorders [26]. In our current study of adolescents from 8 to 16 -year old, lower concentration of $25(\mathrm{OH}) \mathrm{D}$ was found to be associated with higher risk of depression. This finding was independent of many potential confounders as well as the concentration of $25(\mathrm{OH}) \mathrm{D}_{2}$, which was not closely associated with depression. This was not surprising as previous findings have identified $25(\mathrm{OH}) \mathrm{D}_{3}$ as the main contributor to total serum 25(OH)D.

Further, the influence of $25(\mathrm{OH}) \mathrm{D}$ in the risk of developing depressive symptoms was greater in teenagers (12-16 years old) with total $25(\mathrm{OH}) \mathrm{D}$ deficiency than in children $(8-11$ years old). The association of $25(\mathrm{OH}) \mathrm{D}$ with $\mathrm{DD}$ symptoms was stronger in teenagers than children. It is possible that adolescents with low concentrations of $25(\mathrm{OH}) \mathrm{D}$ develop depressive symptoms as a result of chronically insufficient concentrations of 25(OH)D. However, the biological pathways linking $25(\mathrm{OH}) \mathrm{D}_{3}$ to $\mathrm{DD}$ require further investigation.

Urinary iodine is a well-known indicator of iodine intake. The WHO categorized iodine nutritional status as deficiency or excessive iodine intake with cut off levels of 100 and $300 \mu \mathrm{g} / \mathrm{L}$, respectively. Thus, participants in this study were divided into three groups: excessive $(\geq 300$ $\mu \mathrm{g} / \mathrm{L})$, adequate $(100-300 \mu \mathrm{g} / \mathrm{L})$, and deficient $(<100 \mu \mathrm{g} / \mathrm{L})$ iodine intake. lodine is an essential element for the production of thyroid hormones, but the present study shows that the prevalence of DD was higher in the adequate iodine intake group than the excessive group. The stronger association of urinary iodine with $D D$ is an interesting finding. However, the differences could also be affected by possible confounding factors, $25(\mathrm{OH}) \mathrm{D}_{3}$ or outdoor physical activity, which could influence $25(\mathrm{OH}) \mathrm{D}_{3}$ production. Otherwise, in the $25(\mathrm{OH}) \mathrm{D}$ deficient groups, the link between the risk of depression and iodine content was obvious in both DD and control subjects.

In 25(OH)D sufficient and insufficient groups, there was no obvious trend between iodine concentrations and the prevalence of depression. This suggests that serum levels of $25(\mathrm{OH}) \mathrm{D} \geq 20$ $\mathrm{ng} / \mathrm{mL}$ might prevent the development of DD. However, it is also possible that this phenomenon may be a result of the low number of $25(\mathrm{OH}) \mathrm{D}$ deficient subjects, or the relationship between DD and iodine intake is statistically insignificant in a larger population. Given the worldwide iodine abuse, it is important to determine the elements associated with DD in vitamin D-replete populations. The present work suggests that vitamin $D$ sufficiency may prevent the progression and development of DD, regardless of iodine intake. As the exact association between 25(OH)D and iodine remains unclear, our results provide evidence that iodine concentration is associated with $25(\mathrm{OH}) \mathrm{D}$ levels in healthy control patients.

This study had several limitations. This crosssectional study did not clarify the mechanism underlying the impact of serum 25(OH)D and urinary iodine levels on DD. Secondly, the depressive symptoms were diagnosed by selfreported questionnaires to screen for depression, which still remains uncertain. Finally, the volume of dietary vitamin $D$ intake may be possibly affected by the inclusion of subjects with gastrointestinal disorders who might have relatively low serum levels of $25(\mathrm{OH}) \mathrm{D}$ due to poor absorption. Despite these limitations, the present study is important in demonstrating that serum 25(OH)D and urinary iodine are both related to depressive symptoms in adolescents at $8-16$ years of age.

\section{CONCLUSION}

Adolescents with DD have significantly lower levels of serum 25(OH)D and urinary iodine than healthy control patients. Additionally, depression is associated with age, gender, BMI, and smoking.

\section{DECLARATIONS}

\section{Conflict of Interest}

No conflict of interest associated with this work.

\section{Contribution of Authors}

We declare that this work was done by the authors named in this article and all liabilities 
pertaining to claims relating to the content of this article will be borne by the authors. Dehong Gong designed all the experiments and revised the paper. Yongbo Bao performed the experiments, while Wei Huang wrote the paper.

\section{REFERENCES}

1. Thapar A, Collishaw S, Potter R, Thapar AK. Managing and preventing depression in adolescents. BMJ. 2010; 34: 201-209.

2. Lopez $A D$, Murray CC. The global burden of disease, 1990-2020. Nat Med. 1998; 4(11): 1241-1243.

3. Milaneschi $Y$, Hoogendijk W, Lips $P$, Heijboer $A C$, Schoevers $R$, van Hemert AM, Beekman AT, Smit JH, Penninx BW. The association between low vitamin $D$ and depressive disorders. Mol Psychiatry. 2014; 19(4): 444-451.

4. Holick MF. Vitamin D deficiency. N Engl J Med. 2007; 357(3): 266-281.

5. Feldman D, Krishnan AV, Swami S, Giovannucci E, Feldman BJ. The role of vitamin $D$ in reducing cancer risk and progression. Nat Rev Cancer. 2014; 14(5): 342357.

6. Lips $P$, Eekhoff $M$, van Schoor $N$, Oosterwerff $M$, de Jongh $R$, Krul-Poel $Y$, Simsek S. Vitamin $D$ and type 2 diabetes. J Steroid Biochem Mol Biol. 2017; 173: 280285.

7. Rai V, Agrawal DK. Role of Vitamin D in Cardiovascular Diseases. Endocrinol Metab Clin North Am. 2017; 46(4): 1039-1059.

8. Walsh JS, Bowles S, Evans AL. Vitamin D in obesity. Curr Opin Endocrinol Diabetes Obes. 2017; 24(6): 389394.

9. Bertone-Johnson ER. Vitamin $D$ and the occurrence of depression: causal association or circumstantial evidence? Nutr Rev. 2009; 67(8): 481-492.

10. Jorde $R$, Sneve M, Figenschau $Y$, Svartberg J, Waterloo $K$. Effects of vitamin $D$ supplementation on symptoms of depression in overweight and obese subjects: randomized double blind trial. J Intern Med. 2008; 264(6): 599-609.

11. Sanders KM, Stuart AL, Williamson EJ, Jacka FN, Dodd $S$, Nicholson G, Berk M. Annual high-dose vitamin D3 and mental well-being: randomised controlled trial. $\mathrm{Br} \mathrm{J}$ Psychiatry. 2011; 198(5): 357-364.

12. Laurberg P, Pedersen KM, Hreidarsson A, Sigfusson N, Iversen $E$, Knudsen $P R$. lodine intake and the pattern of thyroid disorders: a comparative epidemiological study of thyroid abnormalities in the elderly in Iceland and in Jutland, Denmark. J Clin Endocrinol Metab. 1998; 83(3): 765-769.

13. Sanchez-Villegas A, Perez-Cornago A, Zazpe I, Santiago $S$, Lahortiga F, Martinez-Gonzalez MA. Micronutrient intake adequacy and depression risk in the SUN cohort study. Eur J Nutr. 2018; 57(7): 2409-2419.

14. Lee KJ, Chang SO, Jung KY. Experiences with a lowiodine diet: $A$ qualitative study of patients with thyroid cancer receiving radioactive iodine therapy. Eur $J$ Oncol Nurs. 2016; 23: 43-50.

15. Le Strat $Y$, Dubertret C. A single question to screen for major depression in the general population. Compr Psychiatry. 2013; 54(7): 831-834.

16. Watkins $C$, Daniels $L$, Jack $C$, Dickinson $H$, van Den Broek M. Accuracy of a single question in screening for depression in a cohort of patients after stroke: comparative study. BMJ. 2001; 323(7322): 1159-1168.

17. Misra M, Pacaud D, Petryk A, Collett-Solberg PF, Kappy M, Drug, Therapeutics Committee of the Lawson Wilkins Pediatric Endocrine S. Vitamin D deficiency in children and its management: review of current knowledge and recommendations. Pediatrics. 2008; 122(2): 398-417.

18. Li Y, Lv MR, Wei YJ, Sun L, Zhang JX, Zhang HG, Li B. Dietary patterns and depression risk: A meta-analysis. Psychiatry Res. 2017; 253: 373-382.

19. Li Z, Li B, Song $X$, Zhang D. Dietary zinc and iron intake and risk of depression: A meta-analysis. Psychiatry Res. 2017; 251: 41-47.

20. Roman Vinas B, Ribas Barba L, Ngo J, Gurinovic M, Novakovic $R$, Cavelaars $A$, de Groot $L C$, van't Veer $P$, Matthys $C$, Serra Majem L. Projected prevalence of inadequate nutrient intakes in Europe. Ann Nutr Metab. 2011; 59(2-4): 84-95.

21. Black $L J$, Jacoby $P$, Allen KL, Trapp GS, Hart $P H$, Byrne SM, Mori TA, Beilin LJ, Oddy WH. Low vitamin D levels are associated with symptoms of depression in young adult males. Aust N Z J Psychiatry. 2014; 48(5): 464471.

22. Ng TP, Feng L, Niti M, Kua EH, Yap KB. Folate, vitamin B12, homocysteine, and depressive symptoms in a population sample of older Chinese adults. J Am Geriatr Soc. 2009; 57(5): 871-876.

23. Polak MA, Houghton LA, Reeder Al, Harper MJ, Conner TS. Serum 25-hydroxyvitamin $D$ concentrations and depressive symptoms among young adult men and women. Nutrients. 2014; 6(11): 4720-4730.

24. Gracious BL, Finucane TL, Friedman-Campbell $M$, Messing S, Parkhurst MN. Vitamin D deficiency and psychotic features in mentally ill adolescents: a crosssectional study. BMC Psychiatry. 2012; 12: 38-47.

25. Schneider B, Weber B, Frensch A, Stein J, Fritz J. Vitamin $D$ in schizophrenia, major depression and alcoholism. J Neural Transm (Vienna) 2000; 107(7): 839-842.

26. Wilkins $\mathrm{CH}$, Sheline YI, Roe CM, Birge SJ, Morris JC. Vitamin $D$ deficiency is associated with low mood and worse cognitive performance in older adults. Am J Geriatr Psychiatry. 2006; 14(12): 1032-1040. 